UDC 517

SCOPUS CODE 1101

https://doi.org/10.36073/1512-0996-2021-3-11-20

\title{
Calculation of Vineyard Hail Protection Device
}

\author{
David Tavkhelidze Department of Agro-engineering, Georgian Technical University, 17 D. Guramishvili \\ str, 0192 Tbilisi, Georgia \\ E-mail: d.tavkhelidze@gtu.ge \\ Zurab Mchedlishvili Department of Engineering Graphics and Technical Mechanics, Georgian Technical \\ University, 68 ${ }^{\mathrm{a}}$ M. Kostava str. 0160 \\ E-mail: zurab.mch@mail.ru \\ Omar Tedoradze Department of Agro-engineering, Georgian Technical University, 17 D. Guramishvili \\ str, 0192 Tbilisi, Georgia \\ E-mail: omar.tedoradze@mepa.gov.ge
}

\section{Reviewers:}

T. Mchedlishvili, Professor, Faculty of Transportation and Mechanical Engineering, GTU

E-mail: t.mchedlishvili@gtu.ge

Kh. Gochoshvili, Academic Doctor of Technical Sciences, Ministry of Environment and Agriculture, Department of Agriculture, Food and Rural Development

E-mail: khvica.gochoshvili@mepa.gov.ge

\begin{abstract}
The kinematic and force analysis of an invented new mechanical system used to protect vineyards and other fruit-bearing plants from hail, which often occurs due to climatic changes, is determined. The system contains levers that support anti hail net. The offered mechanical scheme of system is simple and can be used for all type of vineyards. Moreover, the mechanical part of the system can be controlled remotely by a cell phone. In order to determine the mechanical parameters of the system the calculations are given based on the use of the principle of possible displacements, based on what theoretically is determined the necessary volume of weight of load that leads in motion of the system.
\end{abstract}

ISSN 1512-0996

www.shromebi.gtu.ge
Key words: kinematics; load; multi lever mechanism; principle of possible displacements; vineyard.

\section{Introduction}

Georgia is considered to be one of the oldest viticulture and winemaking zones in the world producing high quality wines. The centuries-old experience of wine production has shaped and introduced the traditional technologies of wine making. The vast majority of high quality Georgian wines made using these technologies were successfully sold overseas.

In order to protect vineyards and other fruit-bearing plants from negative atmospheric phenomena, as hail, which have become much more frequent recently due to 
global warming process, commonly use different facilities. Among these facilities has to be distinguished special nets for covering crops during hailing.

There are many schemes of outfits for protection of vineyards and other fertile trees from hail, which include hail proof nets stretched over vineyards supported by poles with different constructions, and ropes of varying configuration. As the example below in the Fig. 1 is given the scheme of the mechanical system for protection of vineyards from hail. The mechanical system contains the tube [1], guide rail [2], piston [3], rod [4], joints of the levers [5], [6], pulleys for rope [7] and
[8], system of ropes with net [9], joints for fixing of levers with tube. At the same time tubes are used as pillars for vineyards. The given mechanical system works due to acting of the high pressure of air or steam launched at the bottom (position 11) of the pipe, which drives the cylinder and hence rode. Depending on the direction of movement of the rod, the protection net opens when hail is intending to come and closes accordingly in good weather. In spite of good work ability of considered mechanical system the disadvantage of these hail protection devices are its complication and accordingly making use of such equipment extremely expensive.
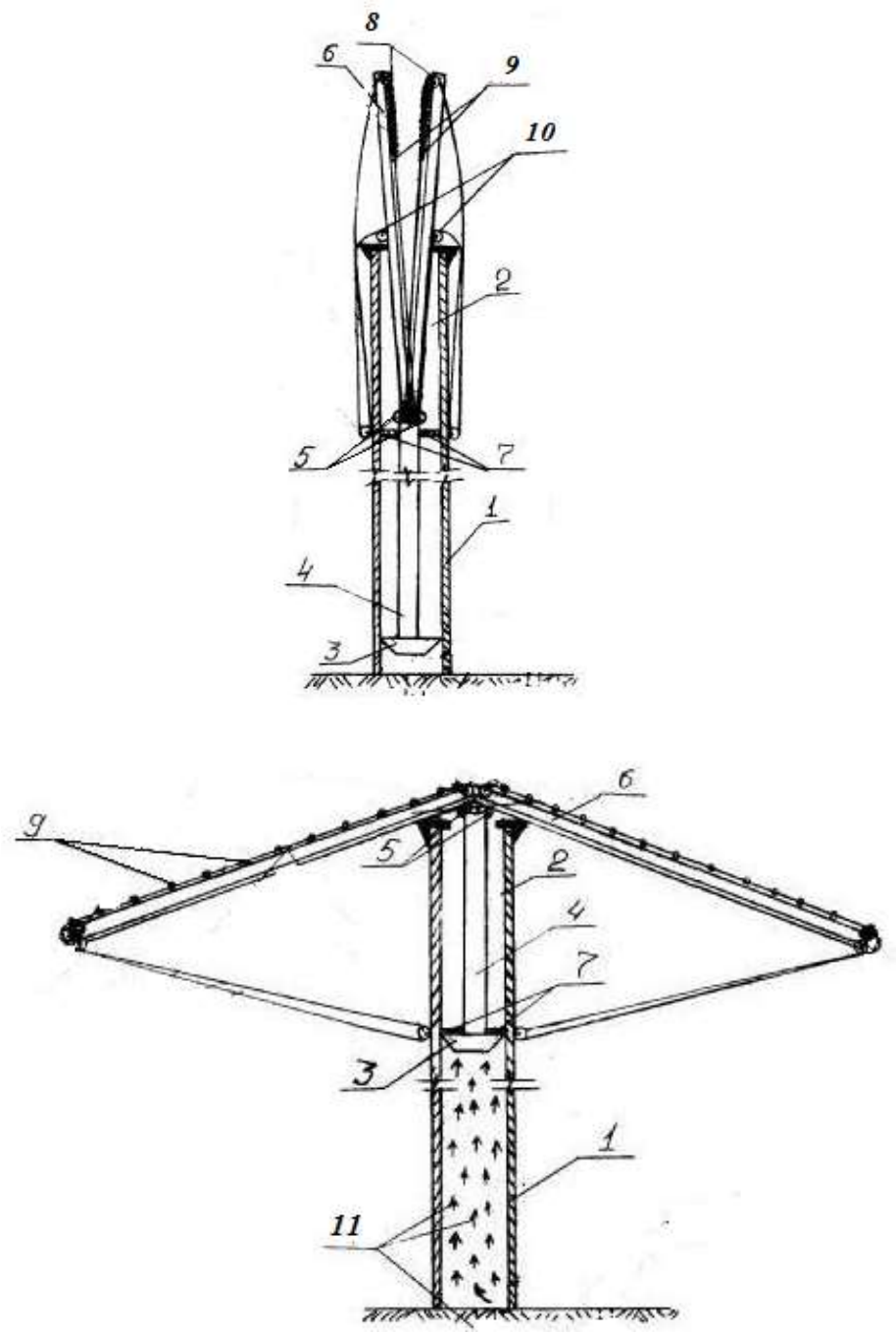

Fig. 1. Example of hail protection device 
In order to avoid above mentioned disadvantages we offer patented new hail protection system the scheme which is illustrated in the Fig. 2.

\section{Main part}

The essence of the invention is to simplify scheme of mechanical system for shutting up and folding down hail proof net. The mentioned system contains pillars with wires for supporting vine trees, where on the top of pillars two levers (see Fig. 2, position 2 and 3) pivotally are mounted. Ends of ropes [5] and [6] are fixed at the levers' ends in the joints,

where the edges of the mesh are fixed with the help of rings [4]. One end of the mentioned ropes is winded on the pulley [13], by the means of block system [12], which is equipped with an electromagnetic contactor to launch the system.

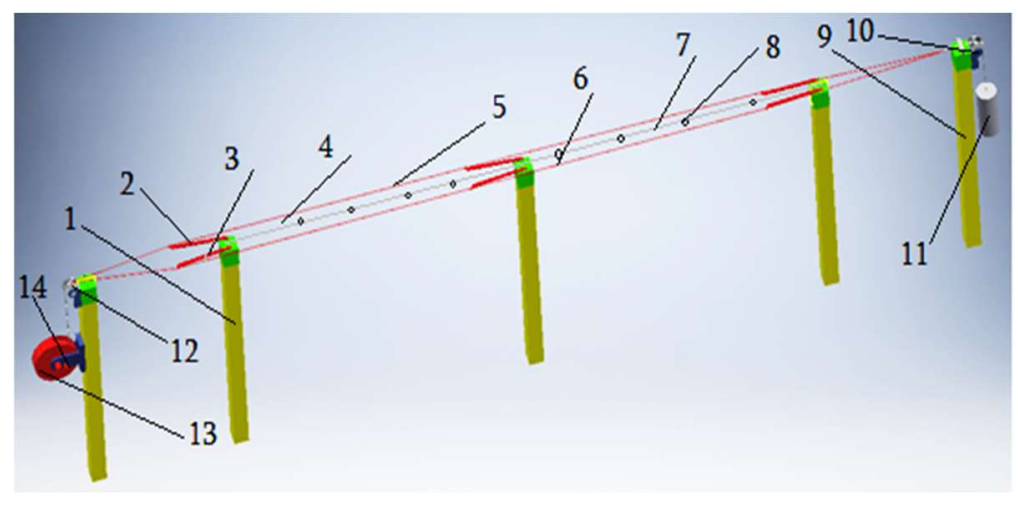

a)

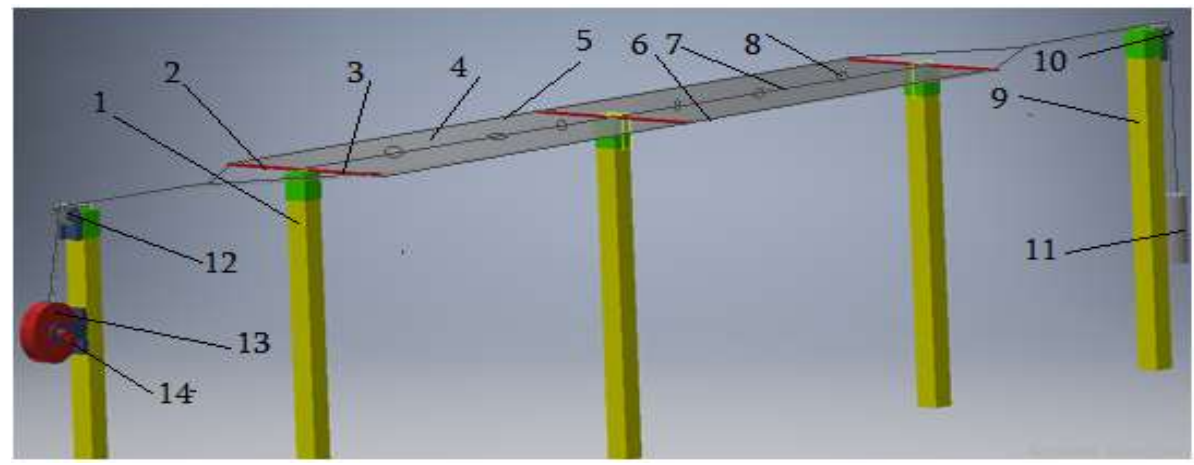

b)

Fig. 2. The net opener in action

In order to spread the net over the vine trees (the initial position of the system is shown in Fig. 2, a), by switching on the contactor, the load [11], suspended at the other end of the jointed ropes, will be moved down, which forced to rotate levers 2 and 3 (see Fig. 2, b) and, as a result, the mesh will spread out.

As we can see, the scheme of the system is very simple and does not need special actuators. However, in order to determine the meaning of weight that would set in motion the system, billow is given the appropriate calculations. Calculation of kinematic and dynamic parameters of the mechanical system.

The main purpose of given calculations is to determine the magnitude of the weight (see Fig. 2, pos.11) whose drop moves in motion the above described anti-hail mechanism. 


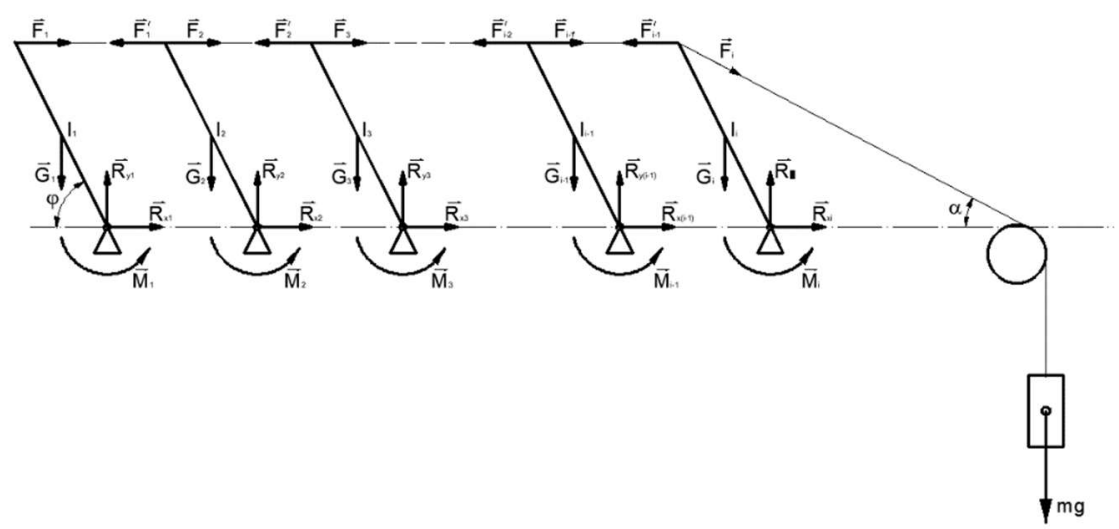

Fig. 3. Design diagram of the mechanism of net opener

The planar motion of the BC lever can be reduced into two simple movements: forward movement along the lever BC and rotational movement around the point C. Consequently, in order to solve this problem, let's use the principle of possible displacement, for which we imagine that the rope as a link BC of the mechanical system has a variable length, for which we denote the possible linear movement of the specified rope by $\delta$ s 1 .

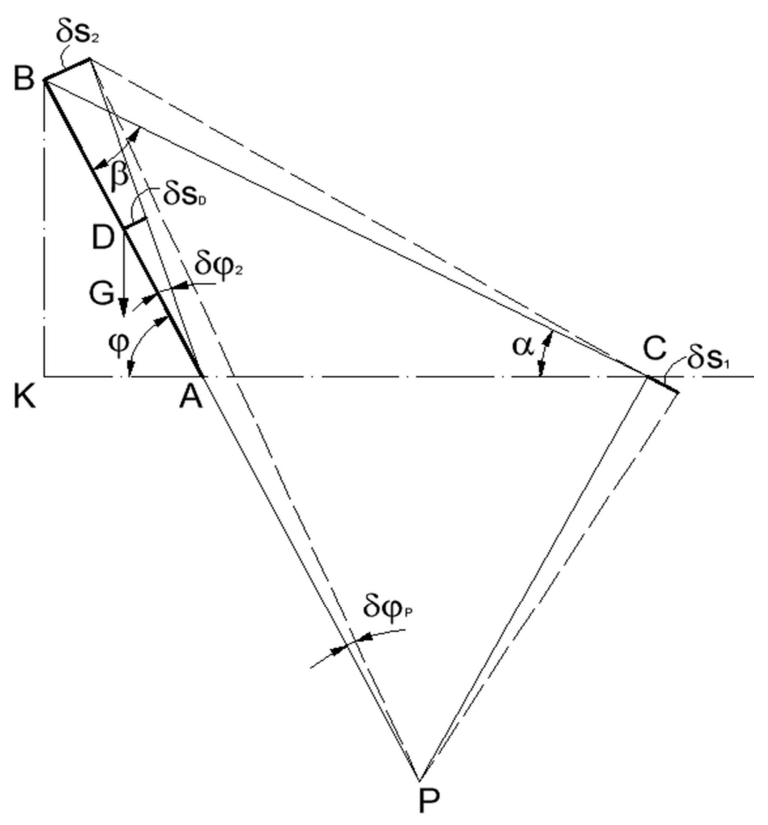

Fig. 4. Design scheme for determination of value of possible displacements

Following the scheme given in Fig.4, it can be seen that the motion of the specified rope leads to the rotation of the $A B$ link relative to the axes fixed on the pillar/pillars (see Fig.2, pos 1) of viniard. Let's denote by $\delta \varphi_{2}$ the possible rotational displacement of the link AB and other simillar links of whole mechanical system.
Using the principle of possible displacements, the equilibrium equation of a mechanical system can be written as:

$$
-M_{A} \cdot \delta \varphi-G_{A B} \cdot \frac{r}{2} \cdot \cos \varphi \cdot \delta \varphi+m g \cdot \delta s_{1}=0
$$


In order to determine constituents of the above given equation it is necessary to consider and analize the triangle CBK, which is given in the Fig.4. It can be determined from this triangle, that

$$
\sin \alpha=\frac{|B K|}{|B C|}
$$

Where $-|B K|=r \cdot \sin \varphi ;|B C|=\sqrt{|B K|^{2}+|K C|^{2}}$

$$
=\sqrt{r^{2} \sin ^{2} \varphi+(d+r \cos \varphi)^{2}} \text {. }
$$

In accordance with the relations given here, it can be written that:

$$
\sin \alpha=\frac{r \cdot \sin \varphi}{\sqrt{r^{2} \sin ^{2} \varphi+(d+r \text { co })^{2}}} .
$$

The next step is to calculate the angle $\beta$, located at the point $\mathrm{B}$ of the triangle CBK. The angle $\beta$ can be defined as:

$$
\beta=180^{\circ}-\left(180^{\circ}-\varphi+\alpha\right)=\varphi-\alpha
$$

To determine the possible displacement of $\delta s_{2}$, it is necessary to find out location of the center of rotation $\mathrm{P}$ of the link BC. For this reason it is necessary to consider the following relations.

$$
\cos \beta=\frac{|B C|}{|B P|}
$$

Where:

$$
|B P|=\frac{|B C|}{\cos \beta}=\frac{\sqrt{r^{2} \sin ^{2} \varphi+(d+r \cos \varphi)^{2}}}{\cos \beta}
$$

and

$$
\begin{gathered}
|C P|=|B P| \cdot \sin \beta= \\
=\sqrt{r^{2} \sin ^{2} \varphi+(d+r \cos \varphi)^{2}} \cdot \operatorname{tg} \beta
\end{gathered}
$$

If we take into account the ratio of possible displacements $\delta s_{2}$ and $\delta s_{1}$ of points $\mathrm{B}$ and $\mathrm{C}$, that is given in the formula (8).

$$
\frac{\delta s_{2}}{|B P|}=\frac{\delta s_{1}}{|C P|}
$$

where

$$
\delta s_{2}=\frac{|B P|}{|C P|} \cdot \delta s_{1}=\frac{\delta s_{1}}{\sin \beta}
$$

you can then calculate the possible angular displacement of the $\mathrm{AB}$ link using the following formula below:

$$
\delta \varphi_{2}=\frac{\delta s_{2}}{r}=\frac{\delta s_{1}}{\mathrm{r} \cdot \sin \beta}
$$

Consequently, there is a displacement of the point $\mathrm{D}$, located in the middle of the link $A B$

$$
\delta s_{D}=\frac{\delta s_{2}}{2}=\frac{\delta s_{1}}{2 r \cdot \sin \beta}
$$

In order to calculate the work done by the force of gravity $\mathrm{G}$ on the displacement $\delta s_{D}$ it is neceessary to determine the meaning of the angle $\cos \left(\widehat{G, \delta s_{D}}\right)$.

$$
\begin{gathered}
\cos \left(\widehat{G, \delta S_{D}}\right)=\cos \left(90^{\circ}-\varphi+90^{\circ}\right)= \\
\cos \left(180^{\circ}-\varphi\right)=-\cos \varphi
\end{gathered}
$$

Taking into account the above relations, the equation of equlibrium (1) of $\mathrm{ABC}$ mechanism in expanded form can be written as:

$$
\begin{aligned}
-M_{A \mathrm{Tp}} & \cdot \frac{\delta s_{1}}{\mathrm{r} \cdot \sin \beta}+G \cdot \frac{\delta s_{2}}{2} \cdot(-\cos \varphi)+ \\
& +m g \cdot \delta s_{1}=0 ; \\
-M_{A \mathrm{Tp}} & \cdot \frac{\delta s_{1}}{\mathrm{r} \cdot \sin \beta}-G \cdot \frac{\delta s_{1}}{2 \sin \beta} \cdot \cos \varphi+ \\
& +m g \cdot \delta s_{1}=0 .
\end{aligned}
$$

For whole mechanical system the equation of equlibrium will have the following view:

$$
\begin{gathered}
-\delta s_{1} \cdot \sum_{i=1}^{n} \frac{M_{i \mathrm{Tp}}}{\mathrm{r} \cdot \sin \beta}- \\
\delta s_{1} \cdot \sum_{i=1}^{n} \frac{\mathrm{G}_{\mathrm{i}} \cdot \cos \varphi}{2 \sin \beta}++m g \cdot \delta s_{1}=0 .
\end{gathered}
$$

From this we will obtain:

$$
m g=\sum_{i=1}^{n} \frac{M_{i \mathrm{Tp}}}{\mathrm{r} \cdot \sin \beta}+\sum_{i=1}^{n} \frac{\mathrm{G}_{\mathrm{i}} \cdot \cos \varphi}{2 \sin \beta}
$$

In order to move the whole mechanism, it is necessary to select a mass for the load whose magnitude satisfies the following inequality:

$$
m>\frac{1}{g} \cdot \sum_{i=1}^{n} \frac{M_{i \mathrm{Tp}}}{\mathrm{r} \cdot \sin \beta}+\frac{1}{g} \cdot \sum_{i=1}^{n} \frac{\mathrm{G}_{\mathrm{i}} \cdot \cos \varphi}{2 \sin }
$$


As we can see in the last formula (17) we have the component $M_{і \text { тр }}$, that represents torque of friction, which are aroused in the place of junction of the link $A B$ with frame fixed on the on the pillars of vineyard. For calculation of the parameter, it is necessary to determine the forces of reactions acted on the pins of mentioned kinematic pairs. The calculations of forces of reaction have to begin from the first pillar, which can be done by writing equations of equilibrium, which are given bellow.

$$
\begin{gathered}
\sum X_{i}=0 F_{1}+R_{1 X}=0 ; R_{1 X}=\frac{G_{1}}{2} \cdot \operatorname{ctg} \varphi . \\
\sum Y_{i}=0 R_{1 Y}-G_{1}=0 ; R_{1 Y}=G_{1} . \\
\sum M_{i}=0 G_{1} \cdot \frac{l_{1}}{2} \cdot \cos \varphi+F_{1} \cdot l_{1} \cdot \sin \varphi=0 .
\end{gathered}
$$

From the given equations it can be obtained the following forces of reaction that are acting along the Cartesian coordinate system.

$$
R_{1 X}=\frac{G_{1}}{2} \cdot \operatorname{ctg} \varphi R_{1 Y}=G_{1}
$$

The same type of equations of equilibrium have to be written for subsequent and other links of mechanical system and hence we will have:

$$
\begin{gathered}
\sum X_{i}=0-F_{1}^{\prime}+F_{2}+R_{2 X}=0 ; \\
\sum Y_{i}=0 R_{2 Y}-G_{2}=0 ;(20) \\
\sum M_{i}=0 G_{2} \cdot \frac{l_{2}}{2} \cdot \cos \varphi+F_{1}^{\prime} \cdot l_{2} \cdot \sin \varphi-F_{2} \cdot l_{2} . \\
\sin \varphi=0 . \\
F_{2}=\frac{G_{2} \cdot \frac{l_{2}}{2} \cdot \cos \varphi+F_{1}^{\prime} \cdot \sin \varphi \cdot l_{2}}{l_{3} \cdot \sin \varphi} \\
=\frac{G_{2} \cdot \cos \varphi+\frac{G_{1}}{2} \cdot \operatorname{ctg} \varphi \cdot \sin \varphi}{\sin \varphi}=\frac{G_{2}}{2} \cdot \operatorname{ctg} \varphi+\frac{G_{1}}{2} \cdot \operatorname{ctg} \varphi .
\end{gathered}
$$

The meaning of forces of reaction can be determined by bellow given expressions

$$
R_{2 X}=\frac{G_{2}}{2} \cdot \operatorname{ctg} \varphi ; R_{2 Y}=G_{2} .
$$

Based on here given expressions the equations of equilibrium for third link can be written as:

$$
\begin{gathered}
\sum X_{i}=0-F_{2}^{\prime}+F_{3}+R_{3 X}=0 ; \\
\sum Y_{i}=0 R_{3 Y}-G_{3}=0 ;
\end{gathered}
$$

$$
\begin{aligned}
& \sum M_{i}=0 G_{3} \cdot \frac{l_{3}}{2} \cdot \cos \varphi+F_{2}^{\prime} \cdot l_{3} \cdot \sin \varphi-F_{3} \cdot l_{3} \cdot \sin \varphi \\
& =0 \text {; } \\
& F_{3}=\frac{G_{3} \cdot \frac{l_{3}}{2} \cdot \cos \varphi+\left(\frac{G_{2}}{2} \cdot \operatorname{ctg} \varphi \frac{G_{1}}{2} \cdot \operatorname{ctg} \varphi\right) \cdot \sin \varphi \cdot l_{2}}{l_{3} \cdot \sin \varphi}=\frac{G_{3}}{2} \cdot \operatorname{ctg} \varphi+ \\
& \frac{G_{2}}{2} \cdot \operatorname{ctg} \varphi+\frac{G_{1}}{2} \cdot \operatorname{ctg} \varphi .
\end{aligned}
$$

For any other link with number $n=i$ can be written as:

$$
F_{i}=\frac{\operatorname{ctg} \varphi}{2} \sum_{n=1}^{i} G_{i}
$$

and meaning of forces of reaction acting on these links would have the following form:

$$
R_{i X}=\frac{G_{i}}{2} \cdot \operatorname{ctg} \varphi ; R_{i Y}=G_{i} .
$$

And hence, the meaning of total forces of reaction would be determined by the following formula:

$$
\begin{gathered}
R_{i}=\sqrt{R_{i X}^{2}+R_{i Y}^{2}}=\sqrt{\frac{G_{i}^{2}}{4} \cdot \operatorname{ctg}^{2} \varphi+G_{i}^{2}}= \\
=G_{i} \cdot \sqrt{\frac{\operatorname{ctg}^{2} \varphi}{2}+1}
\end{gathered}
$$

Based on this expression, it is possible to determine the meaning of frictional moments acting in the places of the movable connection of all links $(n=i)$ with the supports of the vineyard.

$$
M_{t r i}=G_{i} \cdot f \cdot r \cdot \sqrt{\frac{\operatorname{ctg}^{2} \varphi}{2}+1} .
$$

For the last part of the system the equations of equilibrium will be:

$$
\begin{gathered}
F_{i-1}=\frac{c t g \varphi}{2} \sum_{1}^{i-1} G_{i} ; \\
\sum X_{i}=0 ;-F_{i-1}^{\prime}+F_{i} \cdot \cos \alpha+R_{i X}=0 ; \sum Y_{i}=0 ; \\
R_{i Y}-G_{i}-F_{i} \cdot \sin \alpha=0 ; \\
\sum M_{i}=0 ; G_{i} \cdot \frac{l_{i}}{2} \cdot \cos \varphi+F_{i-1}^{\prime} \cdot l_{i} \cdot \sin \varphi+F_{i} \cdot \sin \alpha . \\
l_{i} \cdot \cos \varphi--F_{i} \cdot \cos \alpha \cdot l_{i} \cdot \sin \varphi=0 .
\end{gathered}
$$

From here given equations can be obtained:

$$
\begin{gathered}
\frac{G_{i}}{2} \cdot \cos \varphi+\frac{\operatorname{ctg} \varphi \cdot \sin \varphi}{2} \sum_{1}^{i-1} G_{i}- \\
F_{i} \cdot \sin (\varphi-\alpha)=0 ; \\
F_{i}=\frac{\frac{G_{i}}{2} \cdot \cos \varphi+\frac{\cos \varphi}{2} \sum_{1}^{i-1} G_{i}}{\sin (\varphi-\alpha)}
\end{gathered}
$$

Correspondingly, the forces of reaction acting on the link $A B$ from the frame $A$, can be calculated from the equations given bellow:

$$
\begin{gathered}
R_{i X}=\frac{\operatorname{ctg} \varphi}{2} \sum_{1}^{i-1} G_{i}-\frac{\frac{G_{i}}{2} \cdot \cos \varphi \frac{\cos \varphi}{2} \sum_{1}^{i-1} G_{i}}{\sin (\varphi-\alpha)} \cdot \cos \alpha ; \\
R_{i Y}=G_{i}+\frac{\frac{G_{i}}{2} \cdot \cos \varphi \frac{\cos \varphi}{2} \sum_{1}^{i-1} G_{i}}{\sin (\varphi-\alpha)} \cdot \sin \alpha .
\end{gathered}
$$


From these equations (29) and (30) meaning of the total force of reaction can be written.

$$
\begin{gathered}
R_{i}=\sqrt{R_{i X}^{2}+R_{i Y}^{2}} \\
=\sqrt{\left(\frac{\operatorname{ctg} \varphi}{2} \sum_{1}^{i-1} G_{i}-\frac{\frac{G_{i}}{2} \cdot \cos \varphi+\frac{\cos \varphi}{2} \sum_{1}^{i-1} G_{i}}{\sin (\varphi-\alpha)} \cdot \cos \alpha\right)^{2}+} \\
+{\sqrt{\left(G_{i}+\frac{\frac{G_{i}}{2} \cdot \cos \varphi \frac{\cos \varphi}{2} \sum_{1}^{i-1} G_{i}}{\sin (\varphi-\alpha)} \cdot \sin \alpha\right)}}^{2}
\end{gathered}
$$

After inserting the expressions of these reaction forces (16), we obtain in the formula the force of gravity required to bring the mechanism into motion. In our case we calculate the force of gravity on the load for ten positions of the mechanism when the angle $\varphi$ of inclination of the parallel links changes from $10^{\circ}$ to $80^{\circ}$.

As the example of the above scheme calculation of hail protection system let's use the parameters of the real mechanical system, where the length " $l$ " of each bar is taking equal to $80 \mathrm{~cm}$; weight " $\mathrm{G}$ " of each bar is $0.363 \mathrm{~kg}$; number of bars are $\mathrm{n}=10$; specific weight of each bar is $\gamma=1,305 \mathrm{gram} / \mathrm{cm}^{3}$ and coefficient of friction $-f=0,05$.

Tracing the change in the inclination of the levers of the mechanical system, we calculate the value of the required force to drive the mechanism in action and the change in the value of the force as the configuration of the mechanical system changes. The calculated changes in these parameters are shown below.

When $\varphi_{1}=10^{\circ}$, then $\mathrm{mg}=17.929 \mathrm{~kg} ; \varphi_{2}=20^{\circ}$, then $\mathrm{mg}=8.636 \mathrm{~kg}$;

$$
\begin{aligned}
& \varphi_{3}=30^{0} \text {------ } \mathrm{mg}=5.346 \mathrm{~kg} ; \\
& \varphi_{4}=40^{0} \text {----- } \mathrm{mg}=3.577 \mathrm{~kg} ; \\
& \varphi_{5}=50^{0} \text {------ mg=2.432kg; } \\
& \varphi_{6}=60^{0} \text {------ } \mathrm{mg}=1.602 \mathrm{~kg} ; \\
& \varphi_{7}=70^{0} \text {------ } \mathrm{mg}=0.959 \mathrm{~kg} ; \\
& \varphi_{8}=80^{0} \text {----- mg=0.436kg. }
\end{aligned}
$$

Force changes depending on the angle of inclination of the levers in the form of a graph is given below in Fig. 5.

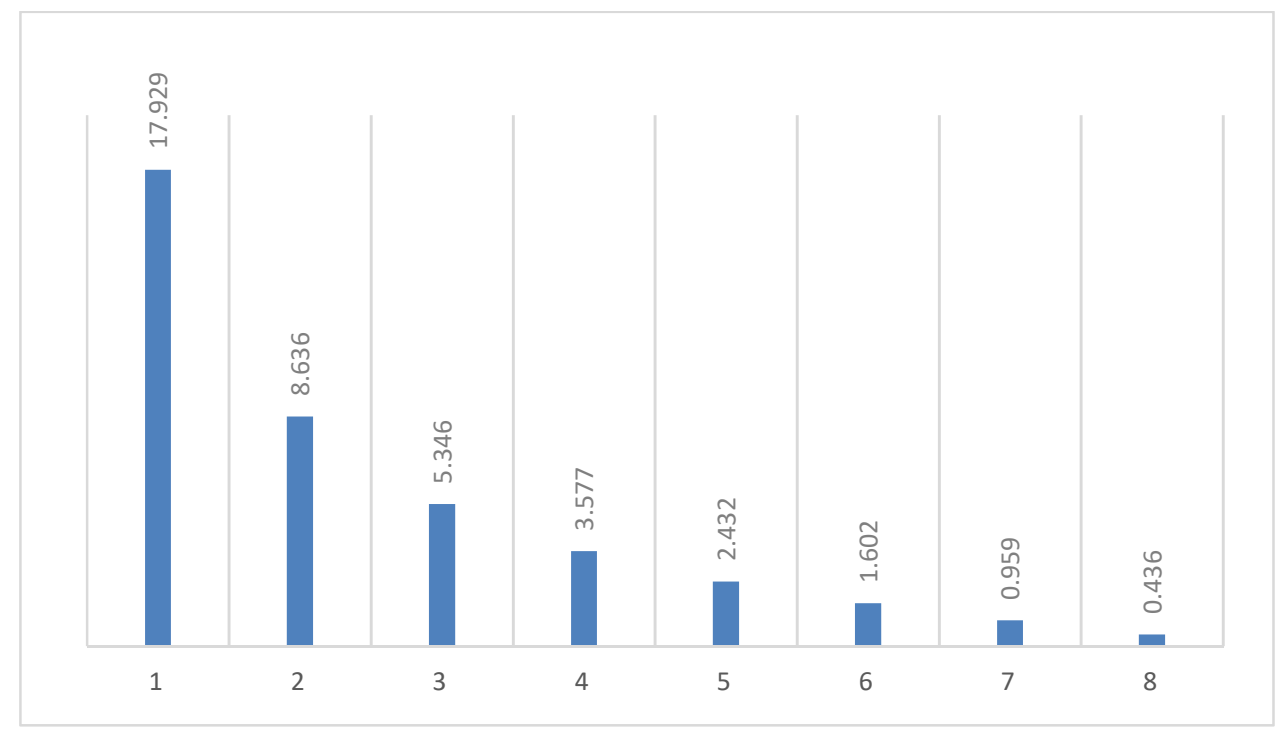

Fig. 5. The chart of relation to angle inclination variation and the force acting on the levers of mechanical system 


\section{Conclusion}

Based on the use of the principle of possible displacement, the practical problem of determining the design parameters of a new anti-hail protection scheme for the vineyard, in which the mechanical system is driven by a controlled drop in the load associated with the levers with the help of levers, is solved. cable system. The principle made possible to calculate the values of the forces acting on the links of the mechanism and, accordingly, the design parameters of the mechanical system can be determined. The offered mechanical system differs from existing systems by its simplicity and as a result by its cheapness and concurrent validity.

\section{References}

1. Goldstein, H., Poole, C. P., Safko, J. L. (2001). Classical Mechanics (3rd ed.). Addison-Wesley.

2. Torby, Bruce. (1984). Energy Principles. Advanced Dynamics for Engineers. HRW Series in Mechanical Engineering. United States of America: CBS College Publishing.

3. Tavkhelidze, D., Mchedlishvili, Z., Janikashvili, M. (2020). Determination of constructive parameters of stair climber's running gear. Works of GTU, N2(512).

4. Myszka, D.H. (2012). Machines and Mechanisms. Prentice Hall. 


\title{
UDC 517
}

SCOPUS CODE 1101

https://doi.org/10.36073/1512-0996-2021-3-11-20

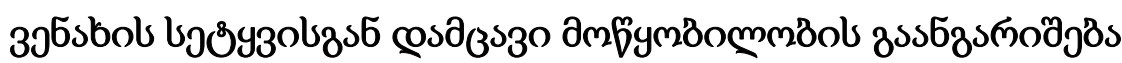

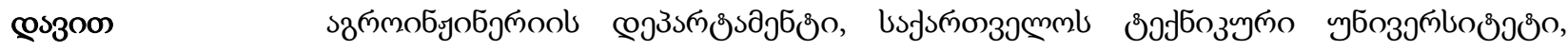

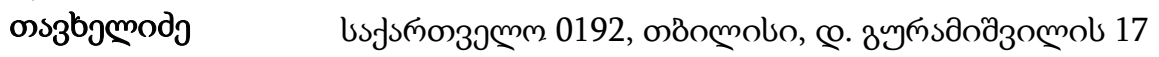 \\ E-mail: d.tavkhelidze@gtu.ge

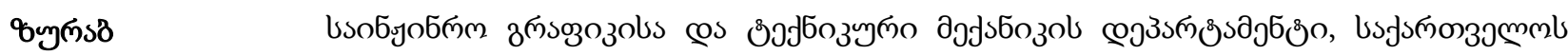

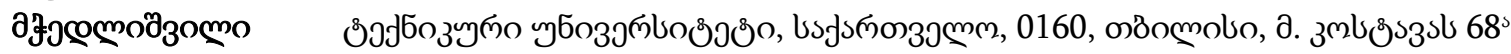 \\ E-mail: zurab.mch@mail.ru

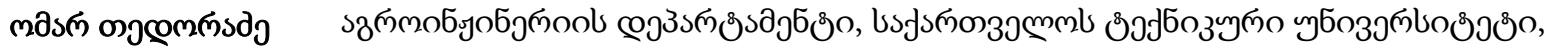

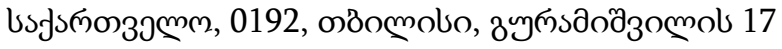 \\ E-mail: omar.tedoradze@moa.gov.ge
}

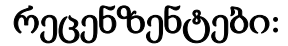

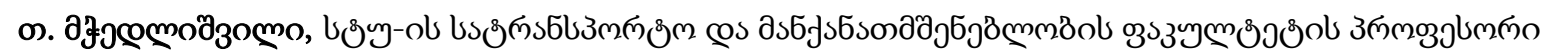

E-mail: T.mchedlishvili@gtu.ge

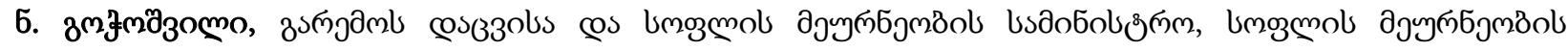

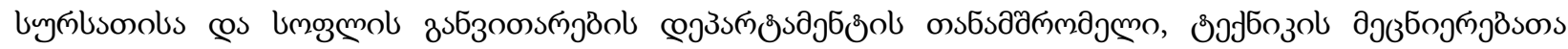

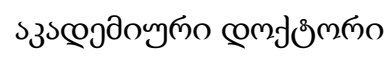

E-mail: khvica.gochoshvili@mepa.gov.ge

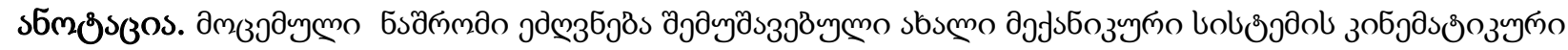

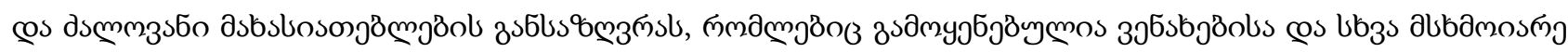

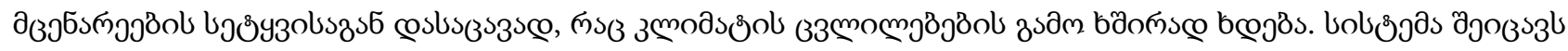

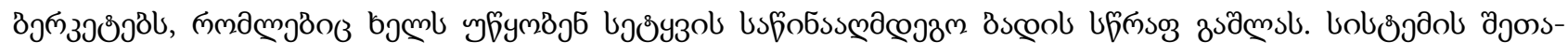

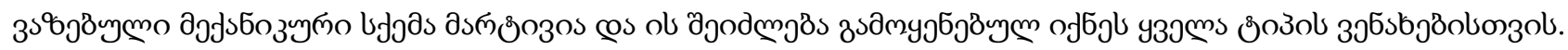

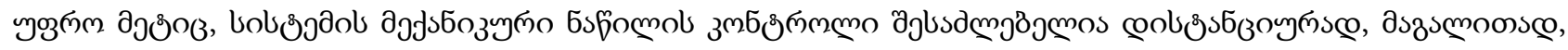

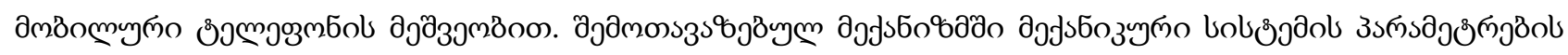

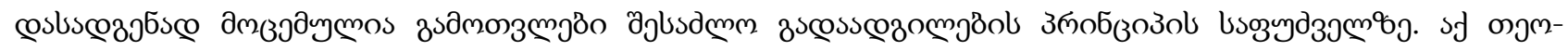

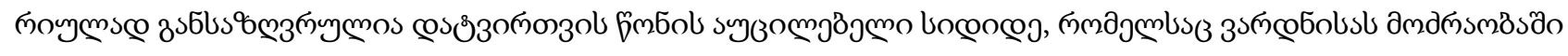

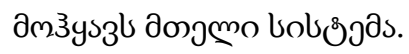

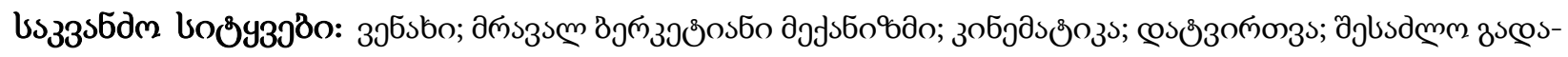
зезомлдов зпобъозо. 
UDC 517

SCOPUS CODE 1101

https://doi.org/10.36073/1512-0996-2021-3-11-20

\title{
Расчет установки по защите виноградников от града
}

\author{
Давид Тавхелидзе Департамент Агроижинерии, Грузинский технический университет, Грузия, 0192, \\ Тбилиси, ул. Д. Гурамишвили 17 \\ E-mail: d.tavkhelidze@gtu.ge \\ Зураб Мчедлишвили Департамент, инженерной графики и технической механики Грузинский \\ технический университет, Грузия, 0160, Тбилиси, ул. Костава $68^{\mathrm{a}}$ \\ E-mail: zurab.mch@mail.ru \\ Омар Тедорадзе Аграрный департамент, Грузинский технический университет, Грузия, 0192, \\ Тбилиси, ул. Гурамишвили 17 \\ E-mail: omar.tedoradze@moa.gov.ge
}

\section{Рецензенты:}

3. Мчедлишвили, профессор факультета транспорта и машиностроения ГТУ

E-mail: T.mchedlishvili@gtu.ge

Х. Гочошвили, Академический доктор технических наук, Министерство окружающей среды и сельского хозяйства, Департамент сельского хозяйства, продовольствия и развития сельских районов

E-mail: khvica.gochoshvili@mepa.gov.ge

Аннотация. Определяется кинематический и силовой анализ изобретенной новой механической системы, используемой для защиты виноградников и других плодовых растений от града, который часто случается из-за климатических изменений. Предлагаемая механическая система содержит систему рычагов и тросов, приводящие в движение противоградовую сетку. Предлагаемая механическая схема системы проста и может использоваться для всех типов виноградников. Для определения механических параметров системы приводятся расчеты, основанные на использовании принципа возможных перемещений, на основании чего теоретически определяется необходимый объем веса груза, приводящего в движение систему.

Ключевые слова: виноградник; возможных перемещений; кинематика; многорычажный механизм; нагрузка; принцип.

The date of review 07.04.2021

The date of submission 07.05.2021

Signed for publishing 29.09.2021 